\title{
Effect of sand-dune slope orientation on soil free-living nematode abundance and diversity
}

\author{
S. PEN-MOURATOV ${ }^{1}$, C. HU ${ }^{1,2}$, E. HINDIN ${ }^{1}$, Y. STEINBERGER ${ }^{1 *}$
}

\begin{abstract}
${ }^{1}$ The Mina \& Everard Goodman Faculty of Life Sciences, Bar-Ilan University, Ramat-Gan 52900, Israel, Email: steinby@mail.biu.ac.il; ${ }^{2}$ Institute of Plant Protection and Soil Science, Hubei Academy of Agricultural Sciences, Wuhan 430064, P. R. China
\end{abstract}

\begin{abstract}
Summary
The spatial and temporal dynamics and composition of a soil free-living nematode community were studied in order to determine the impact of slope orientation on the community on the xeric south- and the mesic north-facing sand-dune slopes.

A significant effect of sampling location on organic matter, total number of free-living nematodes, and trophic diversity was found. Although soil moisture had a significant effect on separate nematode trophic groups and on most of the applied ecological indices, no differences in soil moisture were observed between slopes. Organic matter was found to have a significant effect on the fungivore nematodes. The obtained results indicate that the south-facing slope is more favorable for the observed free-living nematodes than the other sampling sites. Twenty-four of the 77 nematode species that were found in the observed area showed dependence on dune slope orientation. The fungibacteria ratio, Simpson's dominance index, and basal index were useful tools for determining slope differences.
\end{abstract}

Keywords: desert ecosystem; dune; ecological indices; nematode communities; slope orientation; trophic groups

\section{Introduction}

Topography is one of the main factors influencing local microclimate by means of elevation, lateral redistribution of water, and slope orientation, and it, in turn, affects biotic distribution and diversity (Turner et al., 2001; Monger \& Bestelmeyer, 2006).

In the northern hemisphere (Nevo, 1997), south-facing slopes (SFS) receive higher solar radiation associated with higher temperatures and drought than the opposite northfacing slopes (NFS). Previous studies (Nevo, 1997, 2001; Pen-Mouratov et al., 2009) on the co-variation of the relief of an area and the diversity of plant and soil biotic com- munities indicated that the SFS is richer in paleotropical xeric biota, whereas the NFS has higher densities of mesic temperate species. In spite of the small distance between the two slopes, a sharp and significant difference in microclimatic conditions greatly influences the soil biota, leading to an increasing divergence between species located on the south- and north-facing slopes. This difference is more pronounced in xeric environments (Auslander et al., 2003). Moreover, even relatively small-scale changes in relief of an area that occur across low ridges can dictate whether a biotic community is desertified (Monger \& Bestelmeyer, 2006). The considerable effects of slope aspect on the surroundings can be seen in desert ecosystems with complex topography, where sharp and significant differences in microclimate conditions exist between the north-facing slopes (cooler, moister, with higher organic matter availability) and the south-facing counterparts (warmer, dryer, with lower organic matter availability). These differences influence the biology, biodiversity, and ecology of aboveground organisms and lead to an increasing divergence between species located on the different-facing slopes (Dick-Peddie, 1993).

Numerous investigations consider soil free-living nematode communities as one of the most important components of the soil biota (Sohlenius, 1980; Bongers, 1990; Whitford, 2002) and one the most useful indicators of soil quality (Bongers, 1990; de Goede \& Bongers, 1994; Wasilewska, 1994; Gupta \& Yeates, 1997). Our previous investigation showed the importance of the slope orientation of a Plio-Pleistocene canyon dated $3-5$ million years ago and its effect on trophic levels, community structure, and generic diversity of soil free-living nematodes (PenMouratov et al., 2009).

In spite of many scientific publications during the last decade devoted to studying the nematode community in sand-dune habitats (von Bussau, 1990; de Goede et al., 
1993; Goralczyk, 1998; Wall et al., 2002), most focused on coastal-dune ecosystems, whereas only a few were conducted on inland sand-dunes of arid and semiarid environments (e.g., Zhang et al., 2007). These facts indicate that our knowledge of the effect of dune slope orientation on the structure and dynamics of soil free-living nematode communities is insufficient.

An attempt was made in the present study to fill this gap, and to determine the effect of dune slope orientation on soil free-living nematode abundance and diversity in western Negev Desert, Israel.

\section{Materials and methods}

\section{Study site}

The study site was located at the Nizzana sand-dune site within the Hallamish dune field eastern extension of the northern Sinai dune field, western Negev Desert, Israel. The Nizzana-South experimental site is about $45 \mathrm{~km}$ inland from the Mediterranean Sea and the Nizzana-North test site about $32 \mathrm{~km}$. The dune field comprises longitudinal dunes that are aligned west-east, are $15-20 \mathrm{~m}$ high, and are separated by $50-200 \mathrm{~m}$-wide interdunes. The mobile crests of the Nizzana dunes are greatly influenced by exposure to wind due to an almost total lack of vegetation as well as the fact that they have no microbial crust. Mean multi-annual precipitation is $95 \mathrm{~mm}$, with an interannual variability of up to $300 \%$ (Littmann, 1997) and potential evaporation reaching $2600 \mathrm{~mm}$ (Evenari \& Shuval, 1981; Kidron, 2001; Kidron \& Yair, 2001).

Organic matter is severely limited in sandy soil. However, Nizzana dunes do possess a thin microbial crust consisting of cyanobacteria, mosses, and algae, which cover much of the lower part of the dunes, while the mobile crests, the peaks of the dunes, as well as the playa, lack this biological crust (Kidron \& Yair, 1997).

The vegetation found is mainly the perennial Chenopodiaceous species, with Anabasis articulate in the intersanddune valley (Breckle et al., 2008).

\section{Sampling}

A total of 220 soil samples were collected between October 2008 and September 2009 from the upper $(0-10$ $\mathrm{cm})$ and deeper $(10-20 \mathrm{~cm})$ soil layers on the southfacing slope, on the north-facing slope, and in the interdune area. Soil samples were also collected from the middle and top of every of observed slope. Four sample replicates, each $0.5 \mathrm{~kg}$ in weight, were collected from the sampling area. Soil samples were deposited in individual plastic bags that were placed in an insulated container and taken to the laboratory. These soil samples were kept in cold storage at $4^{\circ} \mathrm{C}$ until processing. They were sieved (2$\mathrm{mm}$ mesh size) before biological and chemical analyses in order to remove root particles and other organic debris.

\section{Laboratory analysis}

The following analyses were performed on each sample:

1. Soil water content (SWC) was determined gravimetri- cally as a percentage of dry mass by drying the samples to a constant weight at $105^{\circ} \mathrm{C}$.

2. Soil organic matter $(\mathrm{OM})$ was determined using a modified method of Rowell (1994).

3. The nematode population was determined by extraction from $100 \mathrm{~g}$ fresh soil samples using the Baermann funnel procedure (Cairns, 1999). The recovered organisms were counted using a compound microscope and preserved in formalin. The nematodes from each sample were collected and identified according to order, family, and genus using a compound microscope. Nematodes were classified according to known feeding habitats or stoma and esophageal morphology (Steinberger \& Sarig, 1993; Pen-Mouratov et al., 2004) into the following trophic groups (Yeates et al., 1993): (1) bacteria-feeding; (2) fungi-feeding; (3) plant-parasites; and (4) omnivore-predators. The total number of nematodes was counted and adjusted to $100 \mathrm{~g}$ dry soil.

\section{Ecological indices and statistical analysis}

The characteristics of the nematode communities were described using the following indices: (1) absolute abundance of individuals adjusted to $100 \mathrm{~g}^{-1}$ dry soil TNEM (total number of free-living nematodes); (2) abundance of omnivore-predator (OP), plant-parasitic (PP), fungi-feeding (FF) and bacteria-feeding (BF) nematodes (trophic structure) (Steinberger \& Loboda, 1991; Steinberger \& Sarig, 1993; Liang et al., 2000); (3) $\mathrm{WI}=(\mathrm{FF}+\mathrm{BF}) / \mathrm{PP}$ (Wasilewska, 1994); (4) fungivore/bacterivore (F/B) ratio, $\mathrm{F} / \mathrm{B}=\mathrm{FF} / \mathrm{BF}$ (Twinn, 1974); (5) trophic diversity (T), $\mathrm{T}=1 / \sum \mathrm{P}_{\mathrm{i}}^{2}$, where $\mathrm{P}_{\mathrm{i}}$ is the proportion of the $i$-th trophic group (Heip et al., 1988); (6) Simpson's dominance index ( $\lambda$ ), $\lambda=\sum \mathrm{P}_{\mathrm{i}}^{2}$ (Simpson, 1949); (7) Shannon-Weaver index $\left(\mathrm{H}^{\prime}\right), \quad \mathrm{H}^{\prime}=-\sum \mathrm{Pi}_{\mathrm{I}}\left(\operatorname{lnP} \mathrm{i}_{\mathrm{I}}\right)$, where $\mathrm{p}$ is the proportion of individuals in the $i$-th taxon (Shannon \& Weaver, 1949); (8) maturity index (MI), MI $=\sum v_{i} f i / n$, where $v_{i}$, is the $c-p$ value assigned by Bongers $(1990,1999)$ of the $i$-th genus in the nematode, $f i$ is the frequency of family $i$ in sample and $n$ is the total number of individuals in a sample (Neher $\&$ Darby, 2005). The $c-p$ values describe the nematode life strategies, and range from 1 (colonizers, tolerant to disturbance) to 5 (persisters, sensitive to disturbance); (9) plant-parasite index (PPI) (Bongers, 1990); (10) maturity modification index (MMI), including plant-feeding nematodes (Yeates, 1994); (11) evenness (J'), J'=H'/ln(S), where $\mathrm{S}$ is the number of taxa (Yeates \& King, 1997); (12) species richness, $\mathrm{SR}=(\mathrm{S}-1) / \ln (\mathrm{N})$, where $\mathrm{S}$ is the number of taxa and $\mathrm{N}$ is the number of individuals identified (Yeates \& King, 1997); (13) basal index (BI) $=100 \times(\mathrm{b} /(\mathrm{b}+\mathrm{e}+$ $\mathrm{s})$ ); (14) structure index (SI) $=100 \times(\mathrm{s} /(\mathrm{s}+\mathrm{b}))$, where $\mathrm{b}=$ $0.8 \times(\mathrm{Fu} 2+\mathrm{Ba} 2) ; \mathrm{s}=0.8 \times \mathrm{Ca} 2+1.8 \times \Sigma(\mathrm{X} 3)+3.2 \times$ $\Sigma(\mathrm{X} 4)+5.0 \times \Sigma(\mathrm{X} 5) ; \mathrm{e}=3.2 \times \mathrm{Ba} 1+0.8 \times \mathrm{Fu} 2$; and (15) enrichment index $(\mathrm{EI})=100 \times(\mathrm{e} /(\mathrm{e}+\mathrm{b}))$ (Ferris et al., 2001; Hohberg, 2003; Ferris et al., 2004; Liang et al., 2005).

All data were subjected to statistical analysis of variance using the SAS model (ANOVA, Duncan's multiple range test, and Pearson correlation coefficient) and were used to 

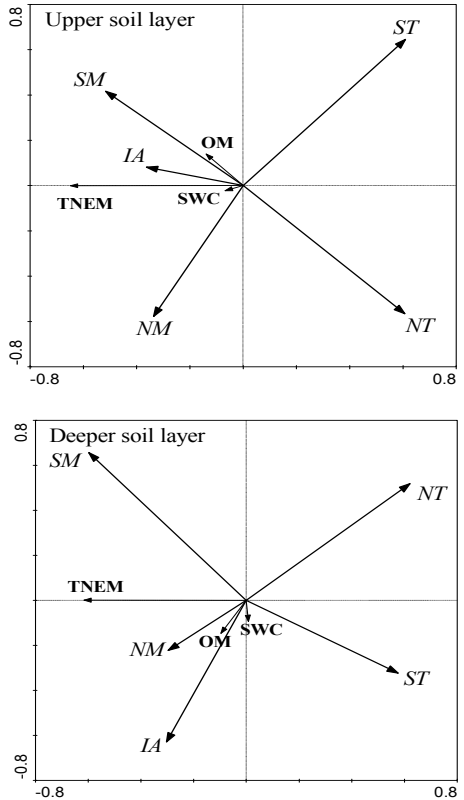

Fig. 1. Redundancy analysis of soil water content (SWC), organic matter (OM), and total number of free-living nematodes (TNEM) with reference to soil properties from the upper and deeper soil layers in the two slopes and inter-dune area.

ST - top of the south-facing slope; NT - top of the north-facing slope; SM - middle part of the south-facing slope; NM - middle part of the north-facing slope; IA - interdune area.

evaluate differences between separate means. CANOCO redundancy analysis (RDA) (ter Braak \& Smilauer, 2002) was conducted in order to evaluate differences between separate means. Differences obtained at levels of $p<0.05$ were considered statistically significant.

\section{Results}

Soil water content (SWC) and organic matter (OM)

Soil water content (SWC) was significantly different between months and depths during the study period with no differences between locations (Table 1). RDA analysis indicated that the upper soil layer of the middle part of both slopes, as well as the interdune area, was moister compared to other sampling locations. Moreover, in the deeper soil layer, SWC values increased in the northern middle plot, the southern top plot, and the interdune area (Fig. 1). OM values indicated differences between months and sampling sites but no differences were found between soil depths (Table 1). OM values were lower at the top of the north-facing slopes and were not significantly different between other sampling sites. RDA analysis showed that OM values were higher in the interdune area of both soil layers, the middle part of the south-facing slope in the upper soil layer, and the middle part of the north-facing slope in the deeper soil layer (Fig. 1). RDA analysis of the observed soil properties explained $35 \%$ of the total variability in both soil layers. The moistest soils were found in February and the driest from May to October. OM values were highest in December and lowest in April-November.

\section{Nematode communities}

The total number of soil nematodes (TNEM) was significantly different among sampling locations at the observed depths (Table 1) and varied from 12 to 151 individuals on the north-facing slope and from 63 to 576 individuals 100 $\mathrm{g}^{-1}$ dry soil on the south-facing slope, whereas nematode variation at the interdune area ranged from 108 to 136 individuals $100 \mathrm{~g}^{-1}$ dry soil. The mean values of the total number of soil nematodes were highest in the middle part of both north- and south-facing slopes and in the interdune area compared to the top of the slopes (Fig. 1). RDA analysis of the total number of soil free-living nematodes explained $35 \%$ of the total variability in both soil layers. The total number of soil nematodes varied between months and was highest in May and lowest in November.

Table 1. Univariate analysis of variance (GLM) for soil properties, nematodes and ecological indices on the different slopes and different altitudes of sand dunes

\begin{tabular}{|c|c|c|c|c|c|c|}
\hline & \multicolumn{2}{|c|}{ Months } & \multicolumn{2}{|c|}{ Location } & \multirow{2}{*}{$\begin{array}{l}\text { Depth } \\
\text { F-test }\end{array}$} & \multirow[b]{2}{*}{$\mathrm{P}$ value } \\
\hline & F-test & $\mathrm{P}$ value & F-test & $\mathrm{P}$ value & & \\
\hline SWC & 296.6 & 0.0001 & 1 & NS & 11.58 & 0.0007 \\
\hline $\mathrm{OM}$ & 22.8 & 0.0001 & 3.76 & 0.005 & 0.25 & NS \\
\hline TNEM & 6.02 & 0.0001 & 76 & 0.0001 & 7.51 & 0.007 \\
\hline $\mathrm{BF}$ & 13.4 & 0.0001 & 72.3 & 0.0001 & 7.61 & 0.006 \\
\hline $\mathrm{FF}$ & 1.91 & 0.04 & 18.2 & 0.0001 & 14.7 & 0.0002 \\
\hline PP & 5.23 & 0.0001 & 31.1 & 0.0001 & 8.62 & 0.004 \\
\hline OP & 2.03 & 0.03 & 36.2 & 0.0001 & 3.86 & 0.05 \\
\hline WI & 16.8 & 0.0001 & 14 & 0.0001 & 20.4 & 0.0001 \\
\hline $\mathrm{F} / \mathrm{B}$ & 0.84 & NS & 11.1 & 0.0001 & 16.6 & 0.0001 \\
\hline $\mathrm{T}$ & 3.6 & 0.0002 & 11.3 & 0.0001 & 0.41 & NS \\
\hline$\lambda$ & 2.82 & 0.003 & 44.1 & 0.0001 & 0 & NS \\
\hline $\mathrm{H}^{\prime}$ & 5.19 & 0.0001 & 106.4 & 0.0001 & 2.09 & NS \\
\hline MI & 9.22 & 0.0001 & 23 & 0.0001 & 3.32 & $\mathrm{NS}$ \\
\hline PPI & 1.68 & NS & 0.62 & NS & 1.76 & $\mathrm{NS}$ \\
\hline MMI & 6.23 & 0.0001 & 13.7 & 0.0001 & 3.52 & 0.06 \\
\hline SR & 2.13 & 0.02 & 22.7 & 0.0001 & 5.41 & 0.02 \\
\hline $\mathrm{EV}$ & 8.7 & 0.0001 & 15.7 & 0.0001 & 0 & NS \\
\hline BI & 3.56 & 0.0002 & 14.5 & 0.0001 & 3.32 & $\mathrm{NS}$ \\
\hline SI & 6.15 & 0.0001 & 21.4 & 0.0001 & 9.73 & 0.002 \\
\hline EI & 3.76 & 0.0001 & 5.04 & 0.0006 & 5.45 & 0.02 \\
\hline \multicolumn{7}{|c|}{$\begin{array}{c}\text { Soil properties: SWC, soil moisture; OM, organic matter. TNEM, total } \\
\text { number of nematodes; trophic structure: BF - bacterivores; } \\
\text { FF - fungivores; PP - plant-parasites; OP - omnivores-predators. } \\
\text { Ecological indices: WI - Wasilewska index; F/B - ratio fungivores/ } \\
\text { bacterivores; trophic diversity (T); Simpson's dominance index }(\lambda) \text {; } \\
\text { Shannon-Weaver index (H'); MI - maturity index; plant-parasite index } \\
\text { (PPI); MMI - modified maturity index; SR - richness; EV - evenness; BI - } \\
\text { basal index; EI - enrichment index; }\end{array}$} \\
\hline
\end{tabular}

Nematode taxa and trophic groups

A total of 77 taxa, including 23 bacteria-feeders, 11 fungifeeders, 24 plant-parasites, and 19 omnivore-predators (Table 2), were found.

Slope location, altitude, and soil depth were found to affect the diversity and abundance of the nematode community (Fig. 2, Table 2). Moreover, the number and density of 
Table 2. The mean relative (\%) change of soil nematode community on the different slopes and altitudes of sand dunes

\begin{tabular}{|c|c|c|c|c|c|c|c|c|c|c|c|}
\hline & & \multicolumn{4}{|c|}{ Upper soil layer } & \multicolumn{6}{|c|}{ Deeper soil layer } \\
\hline & & NT & NM & ST & SM & IA & NT & $\mathrm{NM}$ & ST & $\mathrm{SM}$ & IA \\
\hline b1 & Acrobeles & 0.59 & 2.58 & 1.15 & 11.57 & 0.32 & 1.00 & 2.58 & 1.72 & 9.64 & 1.28 \\
\hline b2 & Acrobeloides & 0.18 & 2.49 & 1.70 & 7.15 & 0.20 & 0.19 & 1.65 & 2.21 & 4.55 & 0.42 \\
\hline b3 & Bunonema & 0.01 & & & & & & & & & \\
\hline b4 & Bursilla & & & 0.04 & & & & & 0.02 & & \\
\hline b5 & Cephalobus & 0.08 & 2.02 & 1.45 & 3.99 & 0.25 & 0.18 & 1.62 & 2.61 & 2.30 & 0.48 \\
\hline b6 & Cervidellus & 0.03 & 0.44 & 0.86 & 1.13 & 0.52 & 0.03 & 0.74 & 1.55 & 0.54 & 0.20 \\
\hline b7 & Chambersiella & 0.01 & & & & & 0.01 & 0.02 & & & \\
\hline $\mathrm{b} 8$ & Chiloplacus & 0.04 & 1.41 & 0.08 & 3.28 & 0.22 & 0.11 & 1.91 & 0.14 & 2.07 & 0.52 \\
\hline b9 & Chronogaster & & & 0.30 & 0.46 & & & 0.04 & & & 0.02 \\
\hline b10 & Eucephalobus & & 0.03 & & 0.14 & & 0.06 & 0.06 & 0.20 & 0.04 & 0.04 \\
\hline b11 & Mesorhabditis & & & & & & & 0.05 & & & \\
\hline b12 & Metateratocephalus & 0.04 & 0.38 & 1.51 & 2.17 & 0.30 & 0.43 & 0.79 & 1.30 & 2.15 & 0.14 \\
\hline b13 & Monhystera & 0.01 & & 0.15 & 0.07 & & 0.01 & & & & \\
\hline b14 & Panagrobelus & 0.01 & & & 0.21 & & 0.03 & 0.02 & & 0.07 & \\
\hline b15 & Panagrolaimus & 0.01 & 0.11 & 0.02 & 0.12 & & 0.03 & 0.04 & 0.11 & 0.04 & 0.01 \\
\hline b16 & Plectus & & 0.03 & & 0.23 & & & & 0.08 & & \\
\hline b17 & Prismatolaimus & & & & & & & & & 0.04 & \\
\hline b18 & Protorhabditis & & 0.04 & 0.01 & & & & & & & \\
\hline b19 & Rhabditis & 0.02 & & 0.02 & 0.68 & & & 0.04 & 0.02 & & 0.02 \\
\hline b20 & Rhabditoides & & & & & & & & 0.02 & & \\
\hline b21 & Teratocephalus & & 0.07 & & 0.34 & 0.04 & & 0.05 & & & 0.11 \\
\hline b22 & Tylocephalus & 0.01 & 0.06 & & 0.14 & & & 0.09 & & & \\
\hline b23 & Wilsonema & 0.01 & 0.54 & 0.27 & 0.40 & 1.17 & & 1.02 & 0.38 & 0.09 & 0.18 \\
\hline $\mathrm{fl}$ & Anguina & & & & 0.17 & & & & & 0.13 & \\
\hline $\mathrm{f} 2$ & Aphelenchoides & 0.07 & 0.27 & 0.04 & 1.73 & 0.60 & & 0.24 & 1.33 & 0.56 & 0.77 \\
\hline $\mathrm{f} 3$ & Aphelenchus & 0.04 & 0.97 & 0.46 & 1.84 & 1.04 & 0.36 & 1.06 & 0.32 & 0.87 & 0.50 \\
\hline $\mathrm{f} 4$ & Aprutides & 0.04 & 0.06 & & & & & & & & \\
\hline f5 & Diphtherophora & & 0.04 & & 0.11 & & & 0.03 & & & \\
\hline f6 & Ditylenchus & 0.15 & 0.12 & 0.02 & 1.05 & & 0.14 & 0.17 & 0.03 & 0.40 & 0.12 \\
\hline f7 & Leptonchus & 0.02 & & & 0.37 & 0.02 & & 0.61 & & 0.04 & 0.05 \\
\hline f8 & Nothotylenchus & 0.23 & & 0.02 & 1.92 & 0.01 & & 0.02 & 0.07 & 0.22 & \\
\hline f9 & Paraphelenchus & & 0.04 & & & 0.27 & 0.06 & 0.11 & & & 0.03 \\
\hline f10 & Tylencholaimus & & 0.20 & 0.02 & 1.20 & 0.01 & & 0.06 & 0.02 & 1.17 & 0.08 \\
\hline f11 & Tylencholaimellus & & 0.01 & 0.02 & 0.05 & & 0.07 & 0.04 & & 0.12 & \\
\hline $\mathrm{p} 1$ & Belonolaimus & & & & & & & & & 0.11 & \\
\hline p2 & Criconema & & & & & & & 0.16 & & 0.12 & \\
\hline p3 & Dolichorhynchus & & & & & & & 0.14 & & 0.32 & \\
\hline p4 & Filenchus & 0.04 & 0.23 & 0.02 & 0.20 & & 0.14 & 0.10 & 0.58 & 0.04 & 0.04 \\
\hline p5 & Heterodera & 0.12 & 0.04 & 0.05 & 0.00 & 0.05 & 0.10 & 0.05 & & 0.02 & 0.04 \\
\hline p6 & Helicotylenchus & 0.02 & 0.06 & & & & 0.01 & 0.02 & & & \\
\hline p7 & Hoplolaimus & 0.03 & 0.06 & & 0.30 & & & & 0.75 & 0.16 & 0.04 \\
\hline p8 & Longidorus & & & & & 0.02 & & & & 0.01 & \\
\hline p9 & Macroposthonia & & & & & & & 0.01 & & & \\
\hline p10 & Macrotrophurus & & & & 0.06 & & & & & & \\
\hline p11 & Malenchus & & & & & & 0.01 & & & & \\
\hline p12 & Meloidodera & & 0.02 & & & & & & & & \\
\hline p13 & Meloidogyne & 0.02 & 0.09 & & & & 0.12 & 0.10 & 0.24 & 0.27 & \\
\hline p14 & Paratylenchus & 0.02 & 0.01 & 0.01 & 0.08 & 0.01 & & 0.05 & & 0.27 & \\
\hline p15 & Pratylenchoides & 0.12 & 0.04 & 0.09 & & & 0.05 & 0.01 & 0.07 & & \\
\hline p16 & Pratylenchus & 0.08 & 0.11 & 0.06 & 0.32 & 0.03 & & 0.26 & 0.85 & 0.63 & 0.09 \\
\hline p17 & Psilenchus & & & & 0.05 & & & & & & \\
\hline p18 & Telotylenchus & & & & 0.16 & & & 0.04 & & 0.21 & 0.16 \\
\hline p19 & Tetylenchus & 0.03 & 0.02 & 0.01 & 0.19 & 0.02 & & 0.02 & & 0.17 & 0.03 \\
\hline p20 & Trichodorus & & & & 0.56 & & & & & 0.03 & \\
\hline p21 & Trophurus & & & 0.01 & & & & 0.19 & & 0.01 & \\
\hline p22 & Tylenchorhynchus & 0.17 & 0.46 & 1.65 & 2.78 & 0.26 & 0.07 & 2.90 & 2.35 & 4.42 & 0.25 \\
\hline p23 & Tylenchus & 0.06 & 0.14 & 0.01 & 0.76 & 0.01 & 0.11 & 0.03 & 0.10 & 0.43 & 0.08 \\
\hline p24 & Xiphinema & & 0.03 & & 0.16 & & 0.02 & & 1.10 & 0.37 & 0.03 \\
\hline ol & Anatonchus & & 0.03 & & & & & & & & \\
\hline $\mathrm{o} 2$ & Aporcelaimus & 0.04 & 0.68 & 3.24 & 4.96 & 0.23 & 0.18 & 0.59 & 4.85 & 2.99 & 0.25 \\
\hline 03 & Aporcelaimellus & 0.06 & 0.32 & 0.02 & 1.84 & 0.49 & 0.12 & 0.30 & & 1.92 & 0.04 \\
\hline 04 & Axonchium & & & & 0.38 & & & & & & \\
\hline 05 & Belondira & & & & & & & 0.01 & & & \\
\hline 06 & Discolaimium & & & & & 0.11 & 0.06 & 0.03 & & 0.07 & \\
\hline 07 & Discolaimus & 0.13 & 0.38 & & 1.08 & 0.05 & 0.12 & 0.07 & 0.09 & 0.61 & 0.04 \\
\hline 08 & Dorydorella & & & & 0.08 & & & & & 0.13 & \\
\hline 09 & Dorylaimellus & & 0.05 & & 0.54 & & & 0.12 & & 0.36 & \\
\hline o10 & Dorylaimoides & & 0.23 & & 0.34 & & & 0.23 & & 0.05 & \\
\hline o11 & Dorylaimus & & 0.13 & & 0.24 & & 0.02 & & & 0.22 & 0.05 \\
\hline o12 & Eudorylaimus & 0.03 & & & 0.45 & & & & & 0.23 & 0.04 \\
\hline o13 & Labronema & & 0.29 & 0.77 & 0.54 & & 0.03 & 0.01 & 1.37 & 0.15 & 0.05 \\
\hline o14 & Mesodorylaimus & 0.03 & 0.15 & 0.11 & 0.76 & & 0.17 & & & 0.44 & \\
\hline o15 & Microdorylaimus & & 0.02 & 0.02 & 0.23 & & 0.06 & 0.03 & & 0.21 & 0.06 \\
\hline o16 & Nygolaimus & & 0.13 & 0.07 & 1.43 & 0.03 & & 0.24 & 4.37 & 0.48 & 0.09 \\
\hline o17 & Paraxonchium & & & & 0.28 & & & & & & \\
\hline o18 & Thonus & & 0.11 & 0.44 & 1.29 & 0.02 & 0.12 & 0.07 & 0.09 & 0.83 & 0.05 \\
\hline o19 & Tripyla & & & & 0.04 & & & & & 0.14 & 0.04 \\
\hline
\end{tabular}

ST - top of the south-facing slope; NT - top of the north-facing slope; SM - middle part of the south-facing slope; $\mathrm{NM}$ - middle part of the north-facing slope; IA - interdune area 

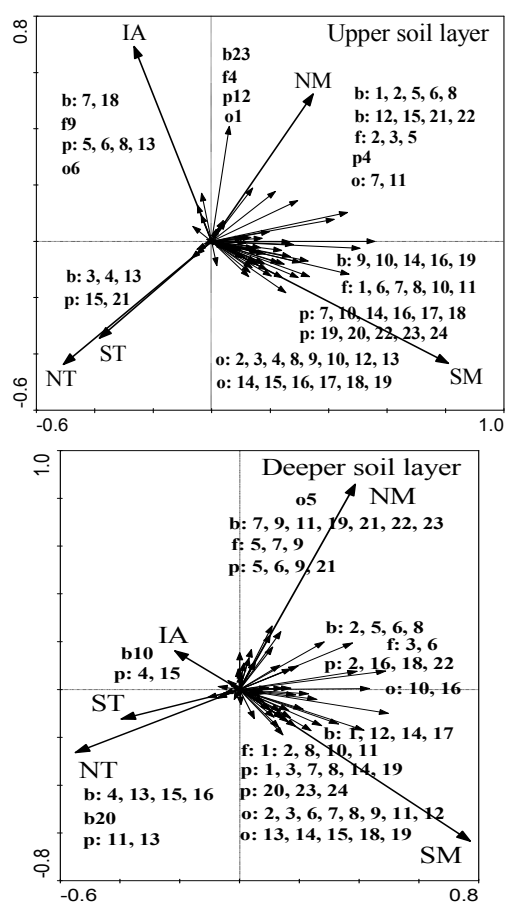

Fig. 2. Redundancy analysis of free-living nematode species (see Table 2) from the upper and deeper soil layers in the two slopes and interdune area. ST - top of the south-facing slope; NT - top of the north-facing slope; SM - middle part of the south-facing slope; NM - middle part of the north-facing slope; IA - interdune area.

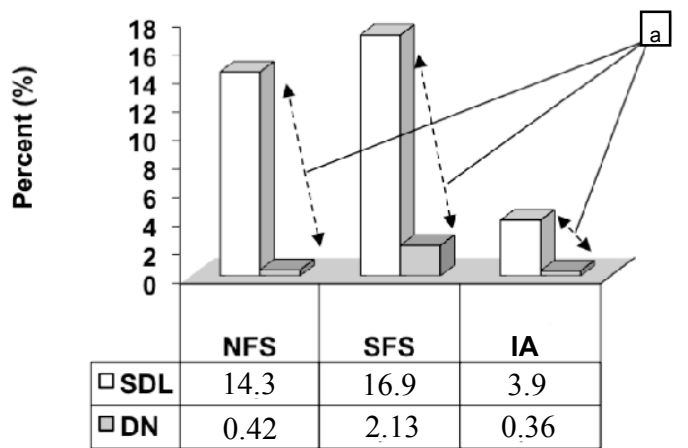

Fig. 3. Percentage of nematode genus dependence on the different sampling-site locations (SDL) and their density (DN) with reference to all nematode genera found in the study area in the different soil layers. SDL - relative abundance (\%) of genera dependent on the different sampling-site locations; DN - density (\%) of nematodes; a - indicates difference between SDL and DN in the different sampling sites. NFS - north-facing slope; SFS - south-facing slope; IA - interdune area.

unique genera of nematodes inhabiting the different slopes and the interdune area were significantly different (Fig. 3). All trophic groups were significantly different between sampling sites at the two depths, during the study period
(Table 1). All observed trophic groups, except fungi-feeding trophic groups, demonstrated the highest values in the middle of the south-facing slope at both depths (Fig. 4). The fungi-feeding nematodes, similar to other trophic groups, exhibited the highest values only at the upper soil layer in the middle of the south-facing slope (Fig. 4). All trophic group densities, except the fungi-feeding nematodes, exhibited a marked trend to decrease both at the top of the slope and in the interdune area on the south-facing slope in both soil layers (Fig. 4).

The total number of observed trophic groups was significantly higher for the south-facing slope than for the northfacing slope, and lowest in the inter-slope area, except for the fungi-feeding trophic groups, which exhibited values that were higher than for the north-facing slope.

The Pearson correlation coefficient indicated positive correlations between SWC and fungi-feeding nematodes and between SWC and omnivore-predators (Table 3). The fungi-feeding nematodes were also positively correlated with OM (Table 3).

\section{Ecological indices}

The ecological indices Wasilewska index (WI), fungivore/bacterivore ratio (F/B), trophic diversity (T), Simpson's dominance index $(\lambda)$, Shannon-Weaver index $\left(\mathrm{H}^{\prime}\right)$ maturity index (MI) and its modification (MMI), species richness (SR), evenness (EV), basal index (BI), structure index (SI), and enrichment index (EI) were all found to differ between locations during the study period (Table 1). However, F/B did not significantly differ between months and $\mathrm{T}, \lambda, \mathrm{H}^{\prime}, \mathrm{MI}, \mathrm{EV}$, and $\mathrm{BI}$ values were indistinguishable between upper and deeper soil layers (Table 1). The plantparasite index (PPI) was the least sensitive and indicated similar values in both soil layers during the study period (Table 1).

A positive correlation was found between SWC and T, H', MI, MMI, EV, and SI, and a negative correlation was found between SWC and WI and BI (Table 1). The F/B, T, $\mathrm{H}^{\prime}$, and SI positively correlated with $\mathrm{OM}$, whereas the WI showed a negative correlation with OM (Table 1).

Results from canonical correspondence analysis of the observed nematode community (Fig. 5) showed a clear difference in values of applied ecological indices between sampling locations. Most of the ecological indices, along with observed soil properties (SWC, OM), were affected by sampling location and increased in the middle part of the NFS, SFS, and the interdune area (Fig. 5). In contradistinction, the values of the Simpson's dominance index $(\lambda)$ revealed a trend to be higher in the north-facing slope and interdune area in the upper soil layer, and at the top of both slopes in the deeper soil layer (Fig. 5). RDA analysis

Table 3. Correlation coefficient between indices of soil organisms and soil conditions of sand dunes in the Negev Desert

\begin{tabular}{|c|c|c|c|c|c|c|c|c|c|c|c|c|c|c|c|c|c|c|}
\hline & TNEM & BF & FF & $\mathbf{P P}$ & OP & WI & $\mathbf{F} / \mathbf{B}$ & $\mathbf{T}$ & $\lambda$ & $\mathbf{H}^{\prime}$ & MI & PPI & MМI & SR & EY & BI & SI & EI \\
\hline SWC & & & $0.14 * *$ & & $0.16^{* *}$ & $-0.22 * *$ & & $0.1^{*}$ & & $0.1 *$ & $0.2 * * *$ & & $0.21 * * *$ & & 0.11 * & $-0.15 * *$ & $0.17 * *$ & \\
\hline OM & & & $0.1 *$ & & & $-0.13 *$ & $0.1 *$ & $0.1 *$ & & $0.1 *$ & & & & & & & $0.11 *$ & \\
\hline
\end{tabular}




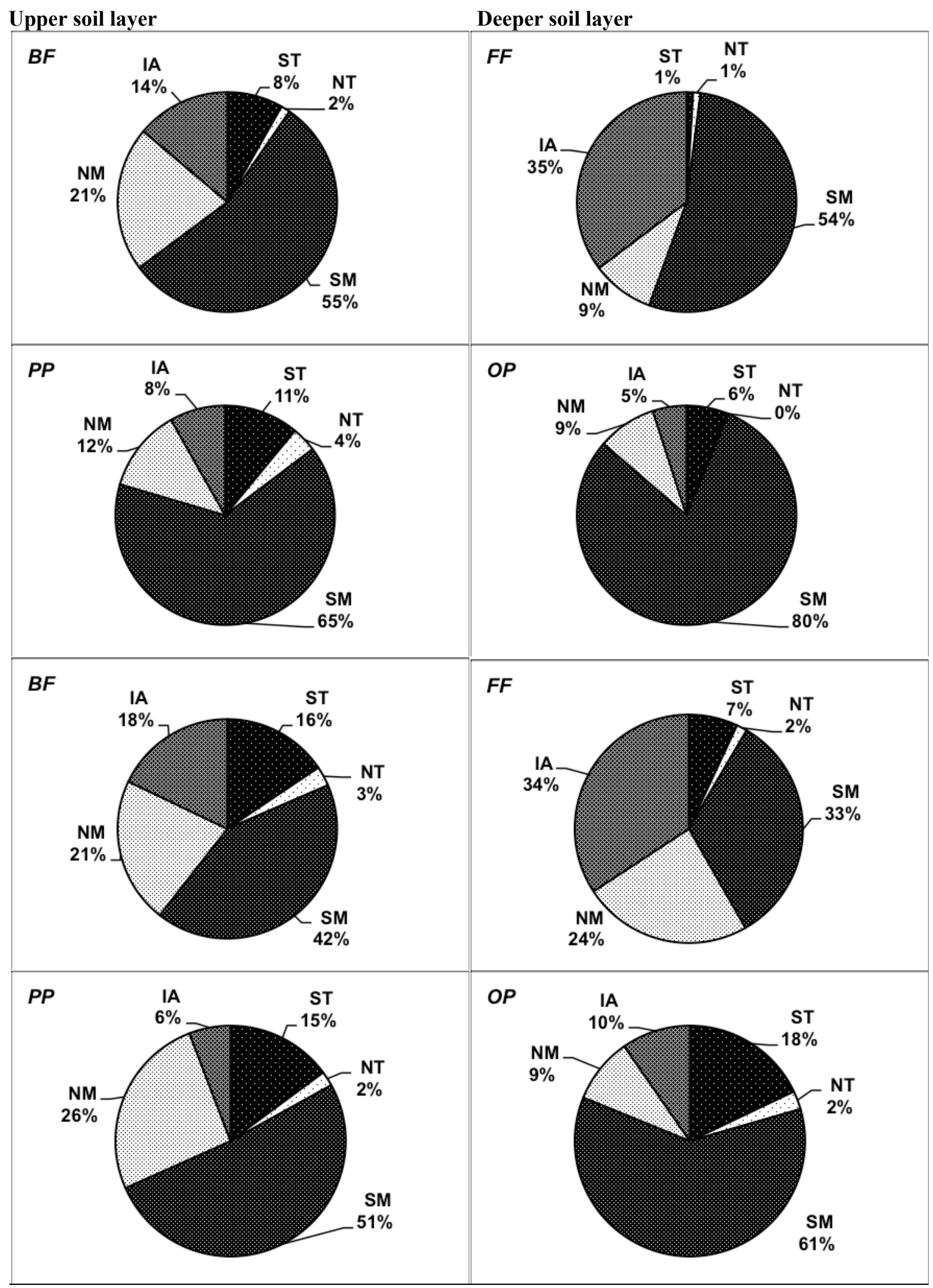

Fig. 4. Distribution of the nematode trophic groups in the different sites of the two slopes. $\mathrm{BF}$ - bacterial-feeding; FF - fungal-feeding; PP - plant-parasitic; OP - omnivore-predator.

ST - top of the south-facing slope; NT - top of the north-facing slope; SM - middle part of the south-facing slope; NM - middle part of the north-facing slope; IA - interdune area. 
of ecological indices explained from 18 to $17 \%$ of the total variability in the upper and deeper soil layers, respectively. The current investigation showed that a difference in environmental conditions on the different studied slopes triggered nematode community divergence. Therefore, although most nematode genera occurred in all observed sampling sites, Anatonchus, Aprutides, Belondira Bunonema, Chambersiella, Helicotylenchus, Macroposthonia, Malenchus, Meloidodera, Mesorhabditis, and Paraphelenchus were observed solely on the north-facing slope. Moreover, Anatonchus, Aprutides, Bunonema, and Meloidodera were observed only in the upper soil layer, while Belondira, Macroposthonia, Malenchus, and Mesorhabditis preferred deeper soil layers, and Chambersiella, Helicotylenchus, and Paraphelenchus were found in both soil layers. In contradistinction to the above-mentioned species, $A n$ guina, Axonchium, Belonolaimus, Bursilla, Dorydorella, Longidorus, Macrotrophurus, Paraxonchium, Psilenchus, Prismatolaimus, Rhabditoides, Trichodorus, and Tripila were observed exclusively on the south-facing slope. Furthermore, Axonchium, Paraxonchium and Psilenchus were found only in the upper soil layer; Prismatolaimus, Rhabditoides, Belonolaimus, and Longidorus were found in the deeper soil layer, but Anguina, Bursilla, Dorydorella, Trichodorus, and Tripila were found in both soil layers.

Longidorus, Tripila, and Paraphelenchus were typical genera of the interdune area. Paraphelenchus was also observed on the north-facing slope and Tripila and Paraphelenchus on the south-facing slope.

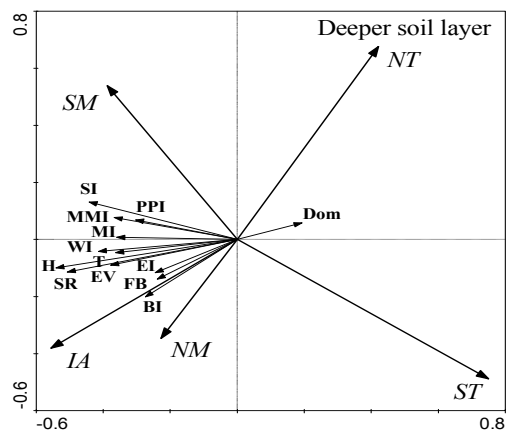

1999), nitrogen and carbon mineralization (Leiros et al., 1999; Savin et al., 2001), and soil organism distribution and activity (Steinberger \& Sarig, 1993). On the other hand, temperature, as one of the principal environmental agents determining soil biotic activity, has been found to be no less influential than soil moisture (Wagai et al., 1998; Uvarov, 2003).

Unique nematode genera typical of other nematode genera comprised from $3.9 \%$ in the interdune area to $14.3 \%$ on the NFS and $16.9 \%$ on the SFS. However, the density of these unique genera of nematodes typical for a certain location was considerably lower, with an average nematode density of $0.36,0.42$, and $2.13 \%$ at the interdune, NFS, and SFS sites, respectively. The obtained values of density and diversity of the observed nematode trophic groups, therefore, indicate that the south-facing slope is more favorable for the observed free-living nematodes than the other sampling sites. Contrary to previous investigations in sand-dune systems reported by De Goede et al. (1993) (Netherlands), Verhoeven (2002) (Germany), and Wall et al. (Wall et al., 2002) (Scotland), where predominance of omnivore-predators followed by bacterivores was found, the obtained result exhibited bacterivore-nematode predominance at the all observed sites. This is consistent with the findings reported by Zhang et al. (2007) (China). Moreover, in both soil layers of the interdune areas, the fungivore nematodes were subdominant, while in the dune slopes the omnivore-predators appeared to be subdominant, except for the deeper soil layer of the north-facing

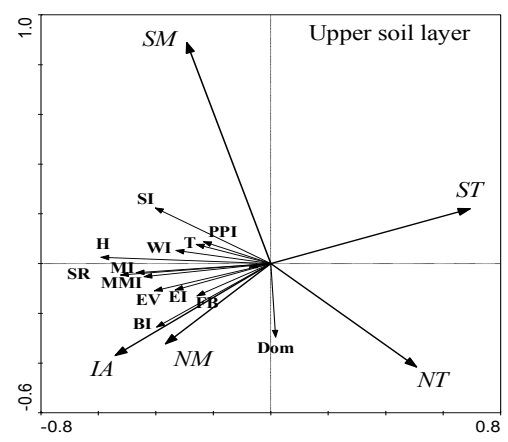

Fig. 5. Redundancy analysis of different ecological indices with reference to soil properties from the upper and deeper soil layers in the two slopes and interdune area. WI - Wasilewska index; FB - fungivore/bacterivore ratio, T - trophic diversity; Dom - Simpson's dominance index; H' Shannon-Weaver index; MI - maturity index; PPI - plant-parasite index; MMI - maturity index modification; EV - evenness; SR - species richness; BI - basal index; SI - structure index; EI - enrichment index; SWC - soil water content; OM - organic matter. ST - top of the south-facing slope; NT - top of the north-facing slope; SM - middle part of the south-facing slope; $\mathrm{NM}$ - middle part of the north-facing slope; IA - interdune area.

\section{Discussion}

Spatial heterogeneity of natural habitats in desert ecosystems is considered to be one of the most important factors leading to a complex and interwoven activity pattern between biotic and abiotic components (Pen-Mouratov et al., 2006). The changes in patch-size heterogeneity are proposed as increasing in proportion to the decrease in soil water availability, where soil moisture availability is known to determine primary production (Saleska et al., slope where omnivore-predators were replaced by plantparasites. This discrepancy in the above-mentioned results can be explained by differences in the edaphic effect on the structure and diversity of nematode communities in colder and warmer regions of the world.

The ecological indices WI, F/B, T, $\lambda, \mathrm{H}$, MI, MMI, SR, $\mathrm{EV}, \mathrm{BI}, \mathrm{SI}$, and EI are sensitive tools for successional changes that occur in sand-dune ecosystems. All applied ecological indices except for $\mathrm{F} / \mathrm{B}, \lambda$, SR, and $\mathrm{EI}$ indicated soil-moisture dependence. Of all ecological indices used in 
the current study, only WI, F/B, T, H', and SI showed dependence on OM. Values of applied indices that reflected nematode species and trophic abundance and diversity (WI, F/B, T, MI, MMI, SR, EV, BI, SI, and EI) and estimated the weight of rare species $\left(\mathrm{H}^{\prime}\right)$ increased from younger successional stages (top of dune with movable sandy soil) to more mature successional stages (middle of slopes and interdune area). In the older successional stages, the trophic and species abundance and diversity of nematodes were higher and more complex, which is in agreement with Odum (1983). The fungi-bacteria $(\mathrm{F} / \mathrm{B})$ ratio which is based on the structure and function of the soil food web and is used as an indicator of ecosystem health (Coleman et al., 1992) was higher in the middle part of the north-facing slope than in the middle of the south-facing slope.

Attention should be turned to the shifts in Simpson's dominance index $(\lambda)$ values from the top of the two observed slopes (in the deeper soil layer) to the north-facing slope and the inter-slope area (in the upper soil layer). On the one hand, the high $\lambda$ values in the younger successional stages (top of observed slopes in the deeper soil layer) might be explained by a more adaptive ability of certain nematode species to rigorous (high-temperature, in this case) environmental conditions (Odum, 1983), while an increase in dominance index values in the more mature successional stages (middle north-facing slope in the upper soil layer) might be explained by the development of more moisture-loving and umbraticolous nematodes. On the other hand, in more umbrageous environments (northfacing slope), the percentage of predominance of fungifeeding nematode species may increase (Coleman et al., 1992), as confirmed by an increase in the $\mathrm{F} / \mathrm{B}$ ratio in the same place.

The basal index (BI), which is used as an indicator of a food web diminished by stress or marked by limited nutrient resources (Ferris et al., 2001; Berkelmans et al., 2003) and as an indicator of the prevalence of general opportunistic nematodes tolerant of soil perturbation (SánchezMoreno et al., 2006), indicated a divergence in soil nematode community development on the different sand-dune slopes.

Taking into account that SWC and OM had no explicit prevalence on either of the observed slopes, we can consider local temperature as the determining factor for the divergence of the nematode communities.

\section{Conclusion}

The middle part of the south-facing slope was found as the most favorable habitat for soil free-living nematodes. Moreover, nematode species sensitive to dune-slope orientation were found. Nevertheless, water content did not differ between the observed slopes, although most of the applied ecological indices indicated a dependence on SWC. We can consider organic matter as the main factor that determines a habitat difference between the observed slopes. However, of all trophic groups, only fungi-feeding nematodes exhibited a correlation with OM. It can, therefore, be assumed that temperature is one of the principal environmental agents, along with soil properties, that determine differences in the soil-biotic habitat in the sanddunes of the Negev Desert.

\section{Acknowledgement}

The authors express their appreciation to Ms. G. Barness for technical assistance.

\section{References}

Auslander, M., Nevo, E., InBar, M. (2003): The effects of slope orientation on plant growth, developmental instability and susceptibility to herbivores. J. Arid Environ., 55: $405-416$

Berkelmans, R., Ferris, H., Tenuta, M., van Bruggen, A. H. C. (2003): Effects of long-term crop management on nematode trophic levels other than plant feeders disappear after 1 year of disruptive soil management. Appl. Soil Ecol., 23: 223 - 235.

Bongers, T. (1990): The maturity index: An ecological measure of environmental disturbance based on nematode species composition. Oecologia, 83: 14 - 19

BONGERS, T. (1999): The Maturity Index, the evolution of nematode life history traits, adaptive radiation and $\mathrm{cp}$ scaling. Plant Soil, 212: $13-22$

Breckle, S. -W., YAIR, A., Veste, M., editors (2008): Arid Dune Ecosystem: The Nizzana Sands in the Negev Desert. Ecological Studies. Vol. 200, Springer-Verlag, Berlin, Heidelberg, Germany

CAIRnS, D. M. (1999): Multi-scale analysis of soil nutrients at alpine treeline in Glacier National Park, Montana. Phys. Geogr., 20: 256-271

Coleman, D. C., Odum, E. P., Crossley, D. A. J. (1992): Soil biology, soil ecology, and global change. Biol. Fertil. Soils, 14: $104-111$

DE Goede, R. G. M., Bongers, T. (1994): Nematode community structure in relation to soil and vegetation characteristics. Appl. Soil Ecol., 1: $29-44$

De Goede, R. G. M., Georgieva, S. S., Verschoor, B. C., KAMERMAN, J. W. (1993): Changes in nematode community structure in a primary succession of blown-out areas in a drift sand landscape. Fundam. Appl. Nematol., 16: $501-513$

Dick-Peddie, W. A. (1993): New Mexico Vegetation: Past, Present and Future. Albuquerque, NM: University of New Mexico Press

EVENARI, M. (1981): Ecology of the Negev Desert: A critical review of our knowledge. In: SHUVAL, H. (Ed) Developments in Arid Zone Ecology and Environmental Quality. Philadelphia, PA: Balaban ISS, pp. 1 - 33

Ferris, H., Bongers, T., DE Goede, R. G. M. (2001): A framework for soil food web diagnostics: extension of the nematode faunal analysis concept. Appl. Soil Ecol., 18: 13 $-29$

Ferris, H., Venette, R. C., Scow, K. M. (2004): Soil 
management to enhance bacterivore and fungivore nematode populations and their nitrogen mineralisation function. Appl. Soil Ecol., 25: 19 - 35

GORALCZYK, K. (1998): Nematodes in a coastal dune succession: Indicators of soil properties? Appl. Soil Ecol., 9: $465-469$

Gupta, V. V. S. R., Yeates, G. W. (1997): Soil microfauna as bioindicators of soil health. In: PANKHURST, $\mathrm{C}$. E., Doube, B. M., Gupta, V. V. S. R., Grace, P. R. (Eds) Soil Biota Management in Sustainable Farming Systems. Oxon, UK: CAB International, pp. $201-233$

Heip, C., Herman, P. M. J., Soetaert, K. (1988): Data processing, evaluation and analysis. In: Higgins, R. P., THIEL, H. (Eds) Introduction to the Study of Meiofauna. Washington, DC: Smithsonian Institution Press, pp. $197-$ 231

HoHBERG, K. (2003): Soil nematode fauna of afforested mine sites: genera distribution, trophic structure and functional guilds. Appl. Soil. Ecol., 22: 113 - 126

KIDRON, G. J. (2001): Runoff-induced sediment yield over dune slopes in the Negev Desert. 2: Texture, carbonate and organic matter. Earth Surf. Proc. Landf., 26: 583 - 599

KIDRON, G. J., YAIR, A. (1997): Rainfall-runoff relationship over encrusted dune surfaces, Nizzana, Western Negev, Israel. Earth Surf. Proc. Landf., 22: 1169 - 1184 KIDRON, G. J., YAIR, A. (2001): Runoff-induced sediment yield over dune slopes in the Negev Desert. 1: Quantity and variability. Earth Surf. Proc. Landf., 26: 461 - 474

Leiros, M. C., Trasar-Cepeda, C., Seoane, S., GilSOTRES, F. (1999): Dependence of mineralization of soil organic matter on temperature and moisture. Soil Biol. Biochem., 31: 327 - 335

Liang, W. J., Pinhasi-Adiv, Y., Shtultz, H., STEINBERGER, Y. (2000): Nematode population dynamics under the canopy of desert halophytes. Arid Soil Res. Rehabil., 14: $183-192$

Liang, W. J., Li, Q., Jiang, Y., Neher, D. A. (2005): Nematode faunal analysis in an aquic brown soil fertilised with slow-release urea, Northeast China. Appl. Soil Ecol., 29: $185-192$

LitTMANN, T. (1997): Atmospheric input of dust and nitrogen into the Nizzana sand dune ecosystem, north-western Negev, Israel. J. Arid Environ., 36: 433 - 457

Monger, H. C., Bestelmeyer, B. T. (2006): The soilgeomorphic template and biotic change in arid and semiarid ecosystems. J. Arid Environ., 65: 207 - 218

NeHER, D. A., DARBY, B. J. (2005): Computation and application of nematode community indices: General guidelines. In: ABEBE, E. (Eds) Freshwater Nematodes: Ecology and Taxonomy. CABI, pp. $211-222$

NEVO, E. (1997): Evolution in action across phylogeny caused by microclimatic stresses at "evolution canyon". Theor. Popul. Biol., 52: $231-243$

Nevo, E. (2001): Evolution of genome-phenome diversity under environmental stress. Proc. Natl. Acad. Sci. U. S. A., 98: $6233-6240$

Odum, H. T. (1983): Systems Ecology: An Introduction. New York: Wiley
Pen-Mouratov, S., He, X. L., Steinberger, Y. (2004): Spatial distribution and trophic diversity of nematode populations under Acacia raddiana along a temperature gradient in the Negev Desert ecosystem. J. Arid Environ., 56: $339-355$

Pen-Mouratov, S., Rakhimbaev, M., Steinberger, Y. (2006): Spatio-temporal effect on soil respiration in finescale patches in a desert ecosystem. Pedosphere, 16: 1-9 Pen-Mouratov, S., Berg, N., Genzer, N., Ukabi, S., Shargil, D., Steinberger, Y. (2009): Do slope orientation and sampling location determine soil biota composition? Front. Biol. China, 4: 364 - 375

Rowell, D. L. (1994): Soil Science: Methods and Applications. London: Longman Group UK Ltd.

SAlESKA, S. R., HARTE, J., TORN, M. S. (1999): The effect of experimental ecosystem warming on $\mathrm{CO}_{2}$ fluxes in a montane meadow. Global Change Biol., 5: 125 - 141

SÁnchez-Moreno, S., CAMArgo, J. A., NAvas, A. (2006): Ecotoxicological assessment of the impact of residual heavy metals on soil nematodes in the Guadiamar River Basin (Southern Spain). Environ. Monit. Assess., 116: $245-262$

Savin, M. C., Gorres, J. H., Neher, D. A., Amador, J. A. (2001): Biogeophysical factors influencing soil respiration and mineral nitrogen content in an old field soil. Soil Biol. Biochem., 33: 429 - 438

SHANNON, C. E., WeAVER, W. (1949): The Mathematical Theory of Communication. Urbana, IL: University of Illinois Press

SIMPSON, E. H. (1949): Measurement of diversity. Nature, 163: 668

SOHLENIUS, B. (1980): Abundance, biomass and contribution to energy flow by soil nematodes in terrestrial ecosystems. Oikos, 34: 186 - 194

STEINBERGER, Y., LOBODA, I. (1991): Nematode population dynamics and trophic structure in a soil profile under the canopy of the desert shrub Zygophyllum dumosum. Pedobiologia, 35: 191 - 197

SteInBERGER, Y., SARIG, S. (1993): Response by soil nematode populations in the soil microbial biomass to a rain episode in the hot, dry Negev Desert. Biol. Fertil. Soils, 16: $188-192$

TER BRAAK, C. J. F., SMILAUER, P. (2002): CANOCO Reference Manual and CanoDraw for Windows User's Guide: Software for Canonical Community Ordination (Version 4.5). Wageningen and Ceske Budejovice: Biometrics TURNer, M. G., GARDNER, R. H., O'NeILL, R. V. (2001): Landscape Ecology in Theory and Practice. New York: Springer

Twinn, D. C. (1974): Nematodes. In: Dickinson, C. H., Pugh, G. J. F. (Eds) Biology of Plant Litter Decomposition. London: Academic Press, pp. $421-465$

Uvarov, A. V. (2003): Effects of diurnal temperature fluctuations on population responses of forest floor mites. Pedobiologia, 47: 331 - 339

VERHOEVEN, R. (2002): The structure of the microtrophic system in a development series of dune soils. Pedobiologia, 46: $75-89$ 
VON BUSSAU, C. (1990): Freeliving nematodes from the coastal dunes and adjoining biotopes of the German and Danish coasts. 1. General part and re-description of some Chromadorida (Nematoda). Zool. Anz., 225: 161 - 188

Wagai, R., Brye, K. R., Gower, S. T., Norman, J. M., BUNDY, L. G. (1998): Land use and environmental factors influencing soil surface $\mathrm{CO}_{2}$ flux and microbial biomass in natural and managed ecosystems in southern Wisconsin. Soil Biol. Biochem., 30: 1501 - 1509

Wall, J. W., Skene, K. R., NeILson, R. (2002): Nematode community and trophic structure along a sand dune succession. Biol. Fertil. Soils, 35: 293 - 301

WASILEWSKA, L. (1994): The effect of age of meadows on succession and diversity in soil nematode communities. Pedobiologia, 38: 1 - 11
Whitford, W. G. (2002): Ecology of Desert Systems. London: Academic Press

YeAtES, G. W. (1994): Modification and qualification of the nematode maturity index. Pedobiologia, 38: 97 - 101

YeAtes, G. W., KING, K. L. (1997): Soil nematodes as indicators of the effect of management on grasslands in the New England Tablelands (NSW): Comparison of native and improved grasslands. Pedobiologia, 41: 526 - 536

Yeates, G. W., Bongers, T., De Goede, R. G. M., Freckman, D., Georgieva, S. S. (1993): Feeding habits in soil nematode families and genera - an outline for soil ecologists. J. Nematol. 25: $315-331$

ZHANG, X. K., LiANG, W. J., JiANG, D. M., LIU, Z. M., JiANG, S. W. (2007): Soil nematode community structure in a Chinese sand dune system. Helminthologia, 44: 204 - 209 